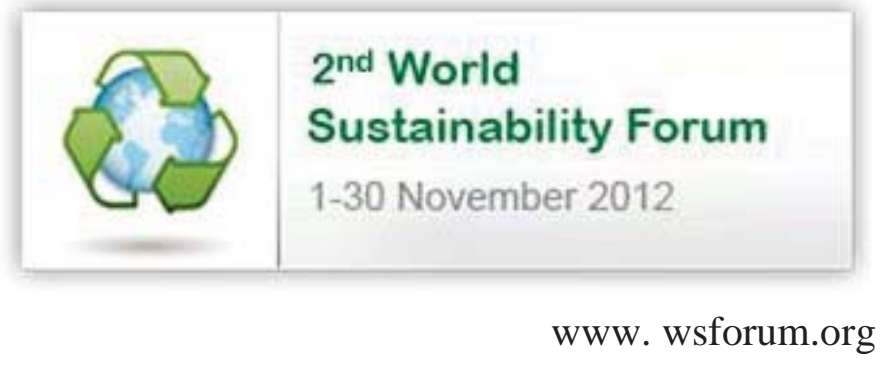

Article

\title{
What do the IUCN categories really protect? A case from the alpine regions in Spain
}

\author{
Lorena Muñoz ${ }^{1}$ and Vera Helene Hausner ${ }^{1} *$ \\ ${ }^{1}$ Department of Arctic and Marine Biology, University of Tromsø, N-9037 Tromsø, Norway \\ E-Mails: lmunoz011@gmail.com; vera.hausner@uit.no \\ * Author to whom correspondence should be addressed; Tel.: +47 77645905; Fax: +47 77646333
}

Received: / Accepted: / Published:

\begin{abstract}
The protected area (PA) coverage is used as an indicator of biodiversity protection worldwide. The effectiveness of using PAs as indicators has been questioned due to the diversity of designations included in such measures, especially those PAs established for other purposes than biodiversity protection. Although international standards have been developed by the International Union for Conservation of Nature (IUCN), the policies on the ground have been developed independently of the IUCN categories. This makes the use of IUCN categories dubious measures of biodiversity conservation. A management plan is crucial for effective management of the parks and for guidance on how biodiversity should be prioritized against other goals. We therefore analyzed the aims and the regulations in management plans of alpine PAs in Spain as a first step for evaluating conservation performance. We used content analysis and CAiv to assess how aims and regulations vary in relation to three explanatory factors: IUCN categories, Vegetation Zones and Autonomous Communities. We found the aims of many parks to be vague, without clear indication on how to prioritize biodiversity goals. Furthermore only 50\% of them actually have a management plan, which strengthens our argument about unclear guidance of PA management. Although aims could partly be related to IUCN categories, the regulations showed no clear relationship to international policies, which reflects that aims are not necessarily implemented in practice. Devolution to Autonomous Communities could be one explanation for the large variation in management practices among parks. Further studies are needed to evaluate the impact of such policies on biodiversity.
\end{abstract}


Keywords: Protected areas, evaluation, management effectiveness, IUCN category, Content Analysis, CAiv, biodiversity, conservation performance, management plan, Spain, alpine, Alpine south, Mediterranean mountain, CBD, monitoring.

\section{Introduction}

Protected areas (PA) have been widely used as measures to deal with biodiversity loss. A well designed network of PAs is usually intended to preserve species richness, habitats and ecosystem processes, thus reducing the rate of species loss. Many PAs were, however, established for other purposes than biodiversity protection, emphasizing recreation or unique cultural values on the national level (Eagles and McCool, 2002; Borgerhoff Mulder and Coppolillo, 2005). Together with the strong variation in management practices, the aims and regulations of the PAs tend to vary extensively. To understand how such PAs could conserve biodiversity there is a need to investigate these differences, including the history and context in which these policies and PAs have evolved.

Since the first National Park was established in Yellowstone in 1872, many different categories have been developed representing a diversity of interests and purposes. The highest increase in the establishment of PAs (and also on the creation of new categories) has been registered after the Convention on Biological Diversity (CBD), which entered into force in 1993. The Conference of parties has also defined PAs coverage as one of the key indicators for measuring effectiveness of biodiversity conservation (Decision VIII/15, CBD, 2006), and a target of $17 \%$ of terrestrial land and inland water areas and $10 \%$ of coastal and marine areas has been set as a minimum area to be effectively protected by 2020 (Decision X/2, CBD, 2010). The use of PA coverage as an indicator to meet the 2020 target has been questioned, as this indicator does not reflect how well PAs are managed (Chape et al., 2005; Coad et al., 2004). Moreover, Butchart et al. (2010) suggested that there is no evidence of slowing down the biodiversity loss despite the increase of PA coverage. Thus, the effectiveness of PAs is a concern that has emerged in the latest years (Ervin, 2003).

There is currently no consensus about the monitoring and evaluation systems needed to effectively manage PAs (Smith and Theberge, 1986; Hockings, 2003; Stem et al., 2005). WCPA (World Commission on Protected Areas) developed a framework for evaluating management effectiveness in PAs recommending the review of 6 stages: the context, planning, inputs, process, outputs and outcomes (Hockings et al., 2006). This approach is commonly referred to as the PAME method (Leverington et al., 2010), and analyzes the whole management process, including status and threats, staff and funding mechanisms, and outcomes. This comprehensive evaluation method has often been cut short by focusing only on a few of the stages, typically those associated with conservation outcomes (Ferraro and Pattanayak, 2006; Bottrill et al., 2011). Rigorous monitoring of populations and biodiversity has usually been preferred, but such evaluations are costly and do not always allow for comparison of parks (Stem et al., 2005). Other evaluation techniques have therefore emerge, such as the use of scorecards, expert assessment, and experience-based knowledge (Ervin, 2003; Stem et al., 2005; Cook et al. 2010; Quan et al., 2011). Among the recent contributions is the System for the Integrated Assessment of Protected Areas (SIAPA) (Rodríguez-Rodríguez and Martínez-Vega, 2012), 
which proposes a PA effectiveness index that goes beyond management effectiveness and that allows comparison of all PAs; not only those with clearly stated management objectives.

Hockings (2003) identified inappropriate policies to be among the factors threatening PAs. He argued that the analysis of policies and management plans (planning stage of the management effectiveness guidelines proposed by WPCA) is essential for the evaluation of the management effectiveness. These documents define the conservation aims of the PA and provide specific regulations of human use. According to Stolton (2004) and Hobbs et al. (2010) the articulation of clear purposes and human activities that are acceptable for meeting conservation goals, is imperative for effective management of PAs. In practice, however, aims are often unclear and highly influenced by other social, economical and political goals than biodiversity protection (Chape 2004; Chape et al., 2005). Both aims and regulations vary among countries, and in some cases also among regions within countries. Moreover, there are parks with weak regulations and enforcement capacity that are named "paper parks" (Rand et al., 2012). These parks are only considered PAs "on paper", and usually fail at achieving conservation goals due to the fact that they are not supported by legislation and/or funding (Stoll-Kleemann and Job, 2008). According to Erwin (1991), it appears that any kind of protection is welcome due to the high and continuous degradation of the environment. Albeit paper parks could protect biodiversity despite the lack of management plans, increasing the funding to manage and regulate human activities will usually improve PA effectiveness (Bruner et al., 2001). The historical diversification, the great variation in aims and management practices, and the increase of protected land surface have raised the necessity of international standards. The International Union for Conservation of Nature (IUCN) was founded in 1948. IUCN defines "protected area" as follows: "A clearly defined geographical space, recognized, dedicated and managed, through legal or other effective means, to achieve the long-term conservation of nature with associated ecosystem services and cultural values" (Dudley, 2008). The IUCN has developed six PA categories to have a worldwide standardized classification of parks. These categories are ordered in different levels of protection depending on the aims and the degree of restrictiveness of the parks. This standardized categorization is a rather new system, used in 1978 for the first time, and adapted in 1994. As a consequence, it is very difficult to assign IUCN categories to PAs established before this system was defined (Dillon, 2004). IUCN has later developed several guidelines for the category assignment, based on the management aims and level of naturalness. Joppa et al. (2008) argued that categories I-IV mainly manage for biodiversity protection, whereas categories $\mathrm{V}$ and VI are managed for a sustainable use of resources, contributing in a lower extent to biodiversity conservation. In the latest years the declaration of the last two categories has increased to allow for integration of conservation with traditional sustainable uses and livelihood concerns. Even if there are several guidelines, there is no regulated procedure for category assignment (EUROPARC-España, 2008). The lack of a regulated procedure for assigning IUCN categories makes evaluation more difficult due to the subjectivity of the authority that assigns it.

Dillon (2004) argues that it is important to analyze how the IUCN category system is implemented in national laws and policies. While differences in management practices between countries is well documented (Bruner et al., 2001; Gaston et al., 2006; Leverington et al., 2010), there have been few studies comparatively evaluating the variation in policies within countries. We meet these challenges by systematically analyzing the aims and management policies in the alpine PAs in Spain. We 
confined ourselves to the Alpine South and the Mediterranean mountains as defined by Mücher et al. (2006) to ensure that human use patterns were comparable. We expected three variables to explain the variation in aims and regulations in the park: (1) IUCN category, (2) the Vegetation Zone in which the PA is located (Alpine South /Mediterranean mountain vegetation zones) and (3) the time period for designation of parks in Autonomous Communities. The IUCN categories were used instead of the national designations due to the high diversity of PA categories in Spain. In addition, the Vegetation Zone where the PAs are located could reflect different management practices between Alpine South Vegetation Zones and Mediterranean Mountains. The Autonomous Communities could potentially be an important explanatory variable as devolution of authority has been determinant for the development of community specific conservation laws. To analyze the relative importance of the IUCN category, Vegetation Zones and Autonomous Communities for the aims and the regulations in the PAs, we used content analysis combined with Correspondence Analysis on Instrumental Variables (Tenenhaus, 1985; Greenacre and Blasius, 2006; Greenacre, 2007). This method allows us to partition the variance in aims and regulations with respect to the IUCN categories, Vegetation Zones and Autonomous Communities (Lebreton et al., 1991).

\subsection{Protection in Spain}

Land and sea protection varies among years depending on the political and economic situation of the countries. Spain is a good example due to its history (i.e. pronounced political and social changes in few years such as the Civil War (1936-1939), the Second World War (1939-1945) and Francisco Franco's dictatorship (1939-1975)). Before the Civil War PAs' policies were progressive as Spain was among the first European countries to establish PAs (the fourth after Sweden, Switzerland and Germany) (Vacas Guerrero, 2005).

In 1916 the first law for the National Parks was established (Ley de 7 de diciembre de 1916, de creación de Parques Nacionales). The law did not clearly define PAs, but it was the first step for the official designation of parks. The first National Park, Parque Nacional de la Montaña de Covadonga, was established in 1918. Authorities soon realized that a high percentage of Spanish natural lands were privately owned, and to avoid the conflicts between conservation goals and owners' goals the government chose to focus on public lands. The focus on public lands has strongly influenced later PAs' policies.

In 1927 a new Royal Decree was passed creating a less restrictive and more flexible category (Natural Sites) compared to National Parks. The revised decree also introduced the compulsory purchasing. This meant that the State could buy private lands by paying the owner a certain amount of money in compensation. However, the lack of funding for purchasing private lands did not allow authorities to buy new territories. During the following years a few new PAs were established, partially because of the lack of funding, but also due to the instability and conflicting political situation that ended up in a Civil War. The consequences of this war together with the Second World War caused a decrease in the rate of nature protection. 
By the year 197023 PAs were declared. However, in 1971 ICONA (National Institute for Nature Conservation) was created and conservation strategies became more important during the 1970's. In 1975 a new law was declared (Ley de 2 de mayo de 1975, de Espacios Naturales Protegidos). Four different categories were defined for both new PAs and old PAs that needed a reclassification. This law was followed by the declaration of 24 new areas in three years. In 1978 the Spanish Constitution devolved PA authority to the government of Autonomous Communities ${ }^{1}$ (with the exception of the declaration and management of National Parks, which was devolved in the following years). This event resulted in a sudden declaration of many PAs (see Figure 1), but also in large differences in the development of protection in different parts of the country (Tolón and Lastra, 2008).

Figure 1: Cumulative curve of protected coverage in Spain. Below are the periods representing parks designated by the different protection laws. Source: Redrawn from Troitiño (1995), Mulero (2002) and EUROPARC-España (2010a).

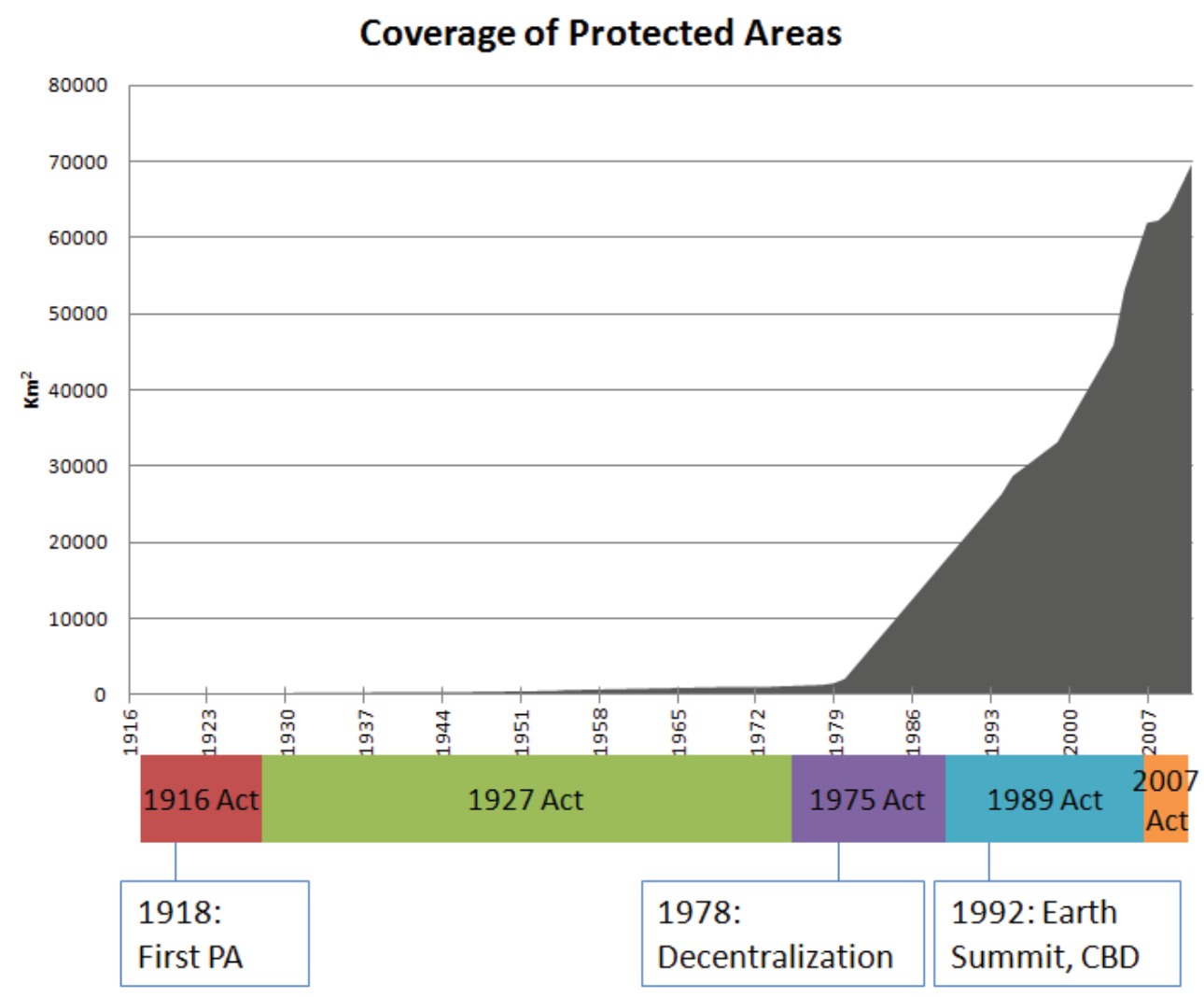

In 1989 a new law was declared (Ley 4/1989, de 27 de marzo, de Conservación de los Espacios Naturales y de la Flora y Fauna Silvestre), which amongst others aimed to create protection networks for the most important and representative ecosystems. Five categories were defined, but it also included the opportunity to create a new category, when necessary, by Autonomous Communities. The

\footnotetext{
${ }^{1}$ Autonomous Communities are territories with similar history, culture or economy that have their own government with rights to declare and execute laws. There are 17 Autonomous Communities (additionally to Ceuta and Melilla).
} 
law added the requirement of a management plan ( $\mathrm{PORN}^{2}$ and $\mathrm{PRUG}^{3}$ in certain categories) in PAs, especially PORNs should be passed before the declaration of some PAs to know the overall condition of the sites and give advice about restrictions of activities.

The late appearance of the law caused problems that the PA system is still facing today. Some of the Autonomous Communities started using their right to manage natural areas before the 1989 Act which has resulted in a mismatch between the legislation of Autonomous Communities and the State's policy. In addition, the opportunity to create new categories others than the ones defined by the 1989 Act resulted in a large diversity of categories (47 in 2002). In addition, there was insufficient coordination and cooperation between Autonomous Communities, as well as with the central government (Mulero, 2002). The lack of communication together with the opportunity to create new protection categories were the reasons for the diversification of categories.

In 2007 a new law was declared (Ley 42/2007, de 13 de diciembre, del Patrimonio Natural y la Biodiversidad). According to Mulero (2008) this new law is important for PA management. The social aspect of conservation gains a lot of importance, involving people affected by PAs in the decision making process and enhancing traditional knowledge. It also considers the economic development and the sustainable use of resources into the policy. There is also an improvement on the definition and content of the management plans, in order to improve the management effectiveness of the parks. The category system, which had been a problem during the previous years, has been highly improved and concepts are more clearly stated. At the same time international agreements were included in the law in order to have a broad conservation approach, such as Natura 2000 network (established under the 1992 Habitats Directive). Natura 2000 is a network of European PAs to preserve the most valuable and threatened species and habitats on the long-term (European Commission, 2012). This approach includes the establishment of networks and ecological corridors for a more effective preservation of resources and biodiversity.

The lack of policies which have coordinated the PA management of central and local governments since the declaration of the 1978 Act has probably resulted in a large variation of aims and regulations of Spanish PAs. Therefore we analyzed how this variation affects management of PAs using the international category system established by the IUCN, which aims to standardize categories for enabling comparisons within and between countries.

\footnotetext{
${ }^{2}$ PORN. (Plan de Ordenación de los Recursos Naturales) The Management Plan for Natural Resources is the instrument for the establishment of boundaries, typification, integration into a network and determination of the relationship with the rest of the territory, for the systems that are part of the heritage and natural resources of a certain place, with independence of other instruments that can be established by the Autonomous Community's legislation (BOE no.299, 2007).

${ }^{3}$ PRUG. (Plan Rector de Uso y Gestión) The Principal Plan for Use and Management is the instrument that regulates the use and regime of the activities yield in the protected area, the type and regime of the resource use and the establishment of different zones with individual restrictions. It also includes rules for the governance of the protected area (Tolón and Lastra, 2008).
} 


\section{Methods and data analysis}

Our study analyzes the adequacy of management policies to meet international standards. However, we also used one variable to capture variation in local management or vegetation zone with regard to aims and regulations of human activities.

\subsection{Study site selection}

There were 1547 PAs in Spain in December 2010 (Banco de Datos de la Naturaleza, 2011). We selected parks in the alpine areas, which are expected to have similar human use patterns, but different management practices. In addition, areas located above 1500 meters height have been highly protected (73\%) in Spain because of their vulnerability to soil erosion (EUROPARC-España, 2010a). Only the parks with $50 \%$ or more of their area covered by this vegetation were selected by using maps from Alterra (Mücher et al., 2006). Besides limiting ourselves to mountainous regions in Spain, we applied the following 3 criteria for selecting parks. The first criterion was that the PAs must be larger than 10 $\mathrm{km}^{2}$. This criterion was important in the IUCN guidelines in 1994 (IUCN, 1994), and we also expected the larger parks to have multiple aims and variable management practices. The selection of alpine parks bigger than $10 \mathrm{~km}^{2}$ was conducted using the GIS program ESRI ArcGIS 10.0 (2010). The second criterion was that all the parks must have a designated IUCN category. There is a high variability of category designation in Spain (Vacas Guerrero, 2005), and we wanted to test how the IUCN designations relate to this variability. The parks' IUCN category in Spanish PAs has been obtained from the Spanish government (Banco de Datos de la Naturaleza, 2011).The third criterion was that the parks must have a management plan (PORN, PRUG and/or public use programs) in use (in English or Spanish) in order to evaluate management practices in the different parks based on comparable parameters of aims and management regulations.

Two map sources were used in this process, one of the vegetation zones from Mücher et al. (2006) and the other one of the boundaries of the Spanish PAs developed by EUROPARC-España (2010c). The first one, LANMAP2 (Alterra), is a Pan-European Landscape Database that classifies 350 different European landscapes (Mücher et al., 2006). Two regions were used in our site selection: the Alpine south and the Mediterranean mountains Vegetation Zones. The map from EUROPARC is updated to December 2009 and contains Spanish PAs defined by the Law 42/2007 of Natural Heritage and Biodiversity and by the Natura 2000 network that were included in the Autonomous Community's legislation (EUROPARC-España, 2010c). EUROPARC did not include PAs established under other International agreements.

\subsection{Variable selection}

Our aim is to study the assignment of the IUCN categories and the differences and similarities in management aims and regulations of the parks located in the alpine zones. For that purpose, three different groups of variables were analyzed. The first one was developed according to guidelines from EUROPARC (EUROPARC-España, 2010b). The second one consists of the management objectives used to assign an IUCN category to the PA. The last group of variables shows whether there are differences in the regulations of human activities. 
We collected the general information regarding each park as stated by EUROPARC guidelines (EUROPARC-España, 2010b), such as the name of the park, the Spanish designation, IUCN category, Vegetation Zone and Autonomous Community it belongs to.

IUCN categories are designated according to the aims of the parks (IUCN, 1994), therefore, we analyzed the management goals for each park. We used directed content analyses (Hsieh and Shannon, 2005) of the available management plans (PORN, PRUG and/or public use programs) as a first step to identify the objectives. We applied categories that were developed according to the goals defined by IUCN guidelines from 1994 (Appendix A 1). IUCN distinguishes between primary objectives, secondary objectives and potentially applicable objectives. However, the ranking of aims has not been implemented to classify PAs in Spain. We therefore recorded the aims only as mentioned (yes) or not mentioned (no) in the management plans.

IUCN categories are also intended to regulate some human activities at national and international levels (EUROPARC-España, 2010a). Thus, the classification of PAs according to aims should correspond to management practices, as biodiversity protection in some cases may need stricter regulations of human activities. Although not sufficient for evaluating performance of PA management, the analyses of regulations could indicate whether aims are implemented in practice. We discarded regulations that were rare and unique for a few parks (e.g. dog entrance, winter sports, climbing). We classified the variables according to four different ordinal levels (see Table 1). The variables with their explanations can be found in the Appendix A 2.

Table 1: Coding and definition for the management regulations' classification.

\begin{tabular}{ll}
\hline Code & Definition \\
\hline No & Activities that are not allowed within the PA's boundaries \\
Permits & Activities that require a permit \\
Restrictions & Activities that are temporarily or spatially restricted \\
& $\begin{array}{l}\text { Activities that are not mentioned in the management plan. This category } \\
\text { also includes activities which could be regulated if harmful to PA } \\
\text { objectives. }\end{array}$ \\
\hline
\end{tabular}

Three predictor variables were expected to have an influence on aims and management of the parks: (1) IUCN category, (2) the Vegetation Zone in which the PA is located (Alpine South/Mediterranean mountain Vegetation Zone) and (3) the Autonomous Community it belongs to. The influence of Autonomous Communities was analyzed by classifying the parks into 3 categories according to the major epochs of PA policies. Category 1 is the Autonomous Communities that established their own law before the 1989 Act was passed. Category 2 Autonomous Communities declared their law subsequently after the 1989 Act was declared and Category 3 encompass the Autonomous Communities that spent a longer time formulating their own legislation for PAs.

\subsection{Statistical analysis}

In this paper we used correspondence analysis with respect to instrumental variables (Caiv) to partition the variation in aims and regulations explained by the IUCN categories, Vegetation Zones and Autonomous Communities (Lebreton et al., 1991). The main advantage of this method compared to logistic regression or log-linear models is that a linear combination of explanatory variables (i.e. IUCN 
categories, Zone and Autonomous Communities) could be used to predict multiple aims and regulations simultaneously. The PCAiv function (Rao, 1964) in the ade4 library package for the R environment (Dray and Dufour, 2007) allows for constrained analyses of the duality diagrams of both numerical and categorical data (see Thioulouse, 2011). We used multiple correspondence analysis as the unconstrained analysis to predict the effects of the three explanatory variables on aims and regulations. The multiple correspondence analysis is an extended version of correspondence analyses and is suitable for sets of homogenous variables that are closely associated (Tenenhaus, 1985; Greenacre and Blasius, 2006; Greenacre, 2007). For regulations we would like to know how well the different regulations of human activities are associated with another, but we would also like to understand the relationships in levels of restrictions (e.g. are typical visitor activities such as camping and campfires not allowed in the IUCN categories with highest degree of protection).

PCAiv could also be compared to Partial Canonical Correspondence Analysis (TerBraak, 1986), including both additive effects and interactions between explanatory variables (Hausner et al., 2003; Killengreen et al., 2012). Given the limited number of parks included in our analyses we decided to explore only additive effects of predictor variables. The pattern derived from the constrained analysis (Caiv) was visually compared to the unconstrained MCA to ensure that key structures in the data had not been missed in the analysis. Finally we performed a Monte-Carlo test on the percentage explained by the models ( $\mathrm{n}=999$ ), which is the sum of eigenvalues divided by the inertia of the unconstrained analysis. All the analyses and graphics were made using the software $\mathrm{R}$ version 2.15 .00 ( $\mathrm{R}$ Development Core Team, 2011) with the ade4 package (Dray and Dufour, 2007). 


\section{Results and Discussion}

The EUROPARC-España's maps included 109 PAs larger than $10 \mathrm{~km}^{2}$ with more than $50 \%$ of the area in the Alpine South and the Mediterranean mountain zones. A total of 38 PAs met the two last criteria of an assigned IUCN category and a management plan available in Spanish or English. From this set two parks were discarded since there was only one park in each category (one category Ib and another category III).

Parks were homogeneously distributed along alpine zones. However, there were more parks in the northern part of Spain due to its larger extent of alpine areas (Figure 2). The 91\% of the PAs in our dataset were established after 1978, which means that the majority was declared by the Autonomous Communities. The proportion of category V parks is also higher (66.67\%) compared to category II and IV.

Figure 2: Map with the selected PAs. Source: Redrawn in ESRI ArcGIS 10.0 by use of LANMAP2 (Alterra) and EUROPARC maps (Background from OINSTITUTO GEOGRÁFICO NACIONAL DE ESPAÑA). Numbers correspond to PAs.

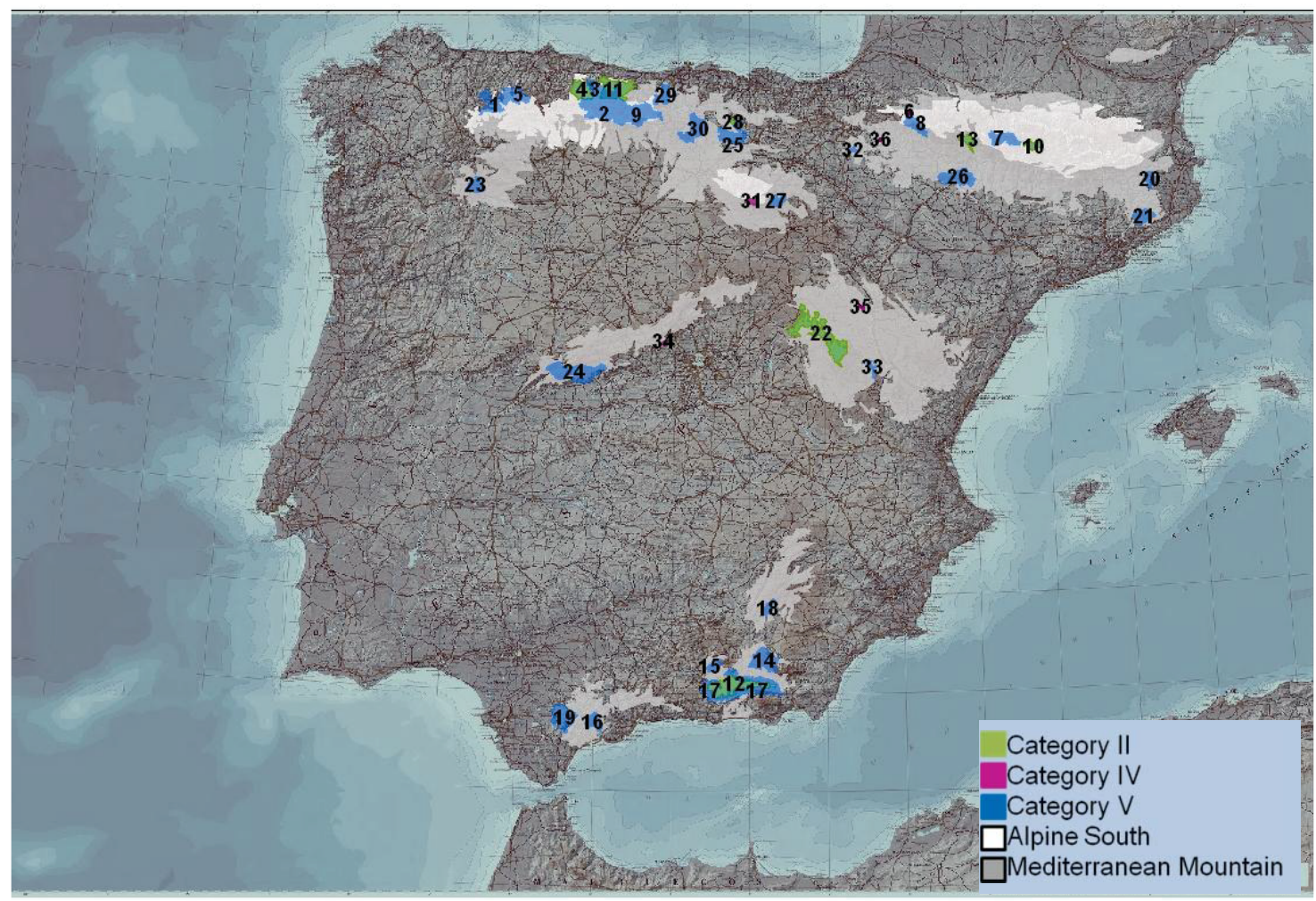

\subsection{Aims}

We found the IUCN categories to explain most of the variance of the aims in the parks (17.05\%), whereas the Autonomous Communities (3.25\%) and the Vegetation Zone (1.19\%) were of minor importance for the differences in aims among parks (Table 2). The plot of the additive models of the 3 predictor variables (24.01\%; $\mathrm{P}=0.04$ ) did not differ substantially from the unconstrained MCA analyses which indicates that no major explanatory variables have been missed in the CAiv analysis. 
Table 2: Percentage explained by each variable with respect to aims and regulations obtained from the CAiv and their significance level according to Monte Carlo permutation tests.

\begin{tabular}{lrrrr}
\hline & AIMS & \multicolumn{3}{c}{ REGULATIONS } \\
\hline & $\%$ & $\mathrm{P}$ & $\%$ & $\mathrm{P}$ \\
IUCN & 17.05 & & 7.89 & \\
CommunityGroup & 3.25 & & 9.85 & \\
Zone & 1.19 & & 3.52 & \\
IUCN+Zone & 19.36 & 0.01 & 11.1 & 0.07 \\
IUCN+CommunityGroup & 22.28 & 0.02 & 17.93 & 0.008 \\
CommunityGroup+Zone & 4.25 & 0.92 & 13.51 & 0.01 \\
IUCN+CommunityGroup+Zone & 24.01 & 0.04 & 21.28 & 0.002 \\
\hline
\end{tabular}

The variance was mainly explained by the first axis (83.15\%) (Figure 3d) and was associated with the IUCN categories (Figure 3a). As a general trend the Categories IV and V do not have clearly stated aims as the Category II does. The second axis (9.57\%) represents the difference in policies between the Autonomous Communities that passed their law earlier and the others. There are not substantial differences between the Alpine and the Mediterranean mountain Vegetation Zones.

Figure 3: Correspondence Analysis on Instrumental Variables (CAiv) on aims. (a) Aims and parks covariance along the two first dimensions. The black background colour means that the goal is mentioned and the grey background means that it is not mentioned. (b) The linear combination of IUCN categories, Autonomous Communities and Vegetation Zones. (c) Projection of the axes of the correspondence analysis into the CAiv. Axis 1 explains $83.14 \%$ of the variation and the second axis $9.57 \%$. (d) Histogram of eigenvalues.

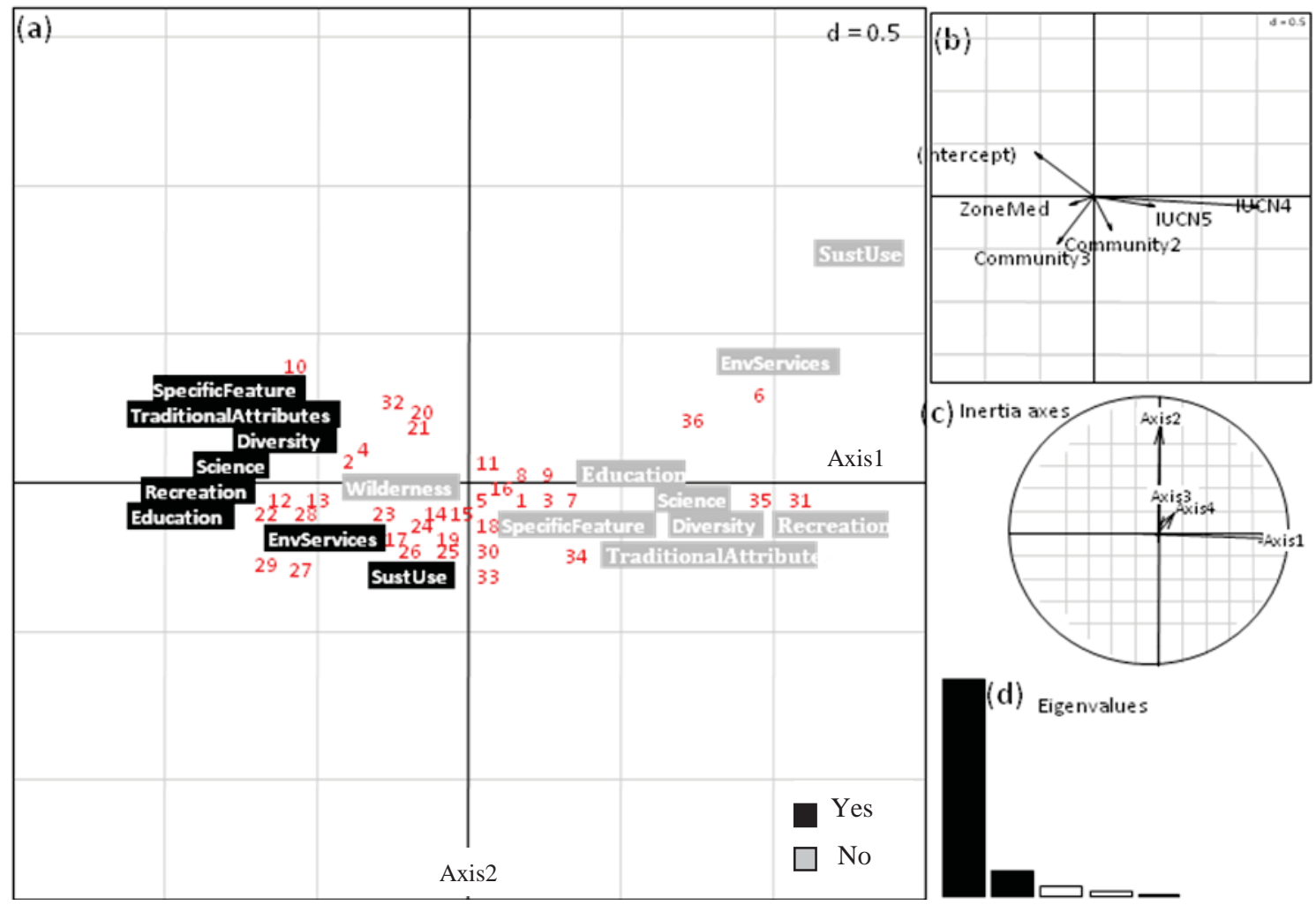




\subsection{Regulations}

The effects of IUCN categories, Vegetation Zones and Autonomous Communities on management practices in the parks were analyzed using 12 different categories of regulations of human activities. As a general result the management practice shows a more diffuse picture than the aims. In contrary to the analysis of the aims the IUCN category explains less of the variance $(7.89 \%)$ compared to the Autonomous Communities (9.85\%) (Table 2). The category II parks have generally a more restrictive management than category IV and V, as the frequency of "No" and "Permits" is higher (Table 3). The Autonomous Communities that established their own management policies earlier have more restrictive management of human activities in the parks (high percentage of "No", see Table 3). Vegetation Zone explains only a minor part of the variance (3.52\%), which could be associated with a bit more restrictive policies in the Alpine Vegetation Zones (see Table 3).

Table 3: Percentage of the restriction level of each IUCN category, Autonomous Communities and Vegetation Zone (Alp for Alpine South and Med for Mediterranean mountains).

\begin{tabular}{crccr}
\hline & $\begin{array}{r}\text { Not } \\
\text { Regulated }\end{array}$ & Restrictions & Permits & No \\
\hline IUCN category & & & & \\
\hline $\mathbf{2}$ & 3.57 & 47.62 & 32.14 & 16.67 \\
$\mathbf{4}$ & 11.67 & 46.67 & 26.67 & 15.00 \\
$\mathbf{5}$ & 10.76 & 52.78 & 30.56 & 5.90 \\
\hline $\begin{array}{c}\text { Autonomous Community } \\
\mathbf{1}\end{array}$ & 22.22 & 27.78 & 30.56 & 19.44 \\
$\mathbf{2}$ & 6.48 & 55.86 & 29.94 & 7.72 \\
$\mathbf{3}$ & 11.11 & 52.78 & 33.33 & 2.78 \\
Vegetation Zone & & & & \\
\hline Alp & 6.82 & 50.76 & 28.03 & 14.39 \\
\hline Med & 10.67 & 51.00 & 31.33 & 7.00 \\
\hline
\end{tabular}

The additive effect of the variables IUCN, Autonomous Communities and Vegetation Zone (Figure 4) explains $21.28 \%$ of the variance, $(\mathrm{P}=0.002$; see Table 2). The Autonomous Communities (first axis, $37.65 \%$ ) and the IUCN (second axis, 30.67\%) account for most of the variance. The IUCN category II and the Autonomous Communities that first established their own laws tend to use the higher regulation levels ("permits" and "no") to a larger extent (Table 3), but the diagram shows that this tendency highly depends on few parks which are very restrictive. The first axis distinguishes parks that use "restrictions" as their major tool versus the parks that do not specify regulation of typical recreational activities such as making campfires, riding bikes and horses or driving motorized vehicles within the park boundaries (Figure 4a and d). The second axis reflects to a larger extent the general tendencies of IUCN category II for stricter regulations of parks, with a higher frequency of "not" allowed activities, compared to category IV and V. The comparison with the unconstrained analysis shows approximately the same general pattern. However, most parks are aggregated around origo and there are no indications of a strong relationship between regulations and explanatory variables 
Figure 4: Correspondence Analysis on instrumental variables (CAiv) ordination for management regulations. (a) Management regulations and parks covariance along the two first dimensions. (b) The linear combination of IUCN categories, Autonomous Communities and Vegetation Zones. (c) Projection of the axes of the correspondence analysis into the CAiv. The first axis explains $37.65 \%$ of the variation and the second axis $30.67 \%$. (d) Histogram of eigenvalues.

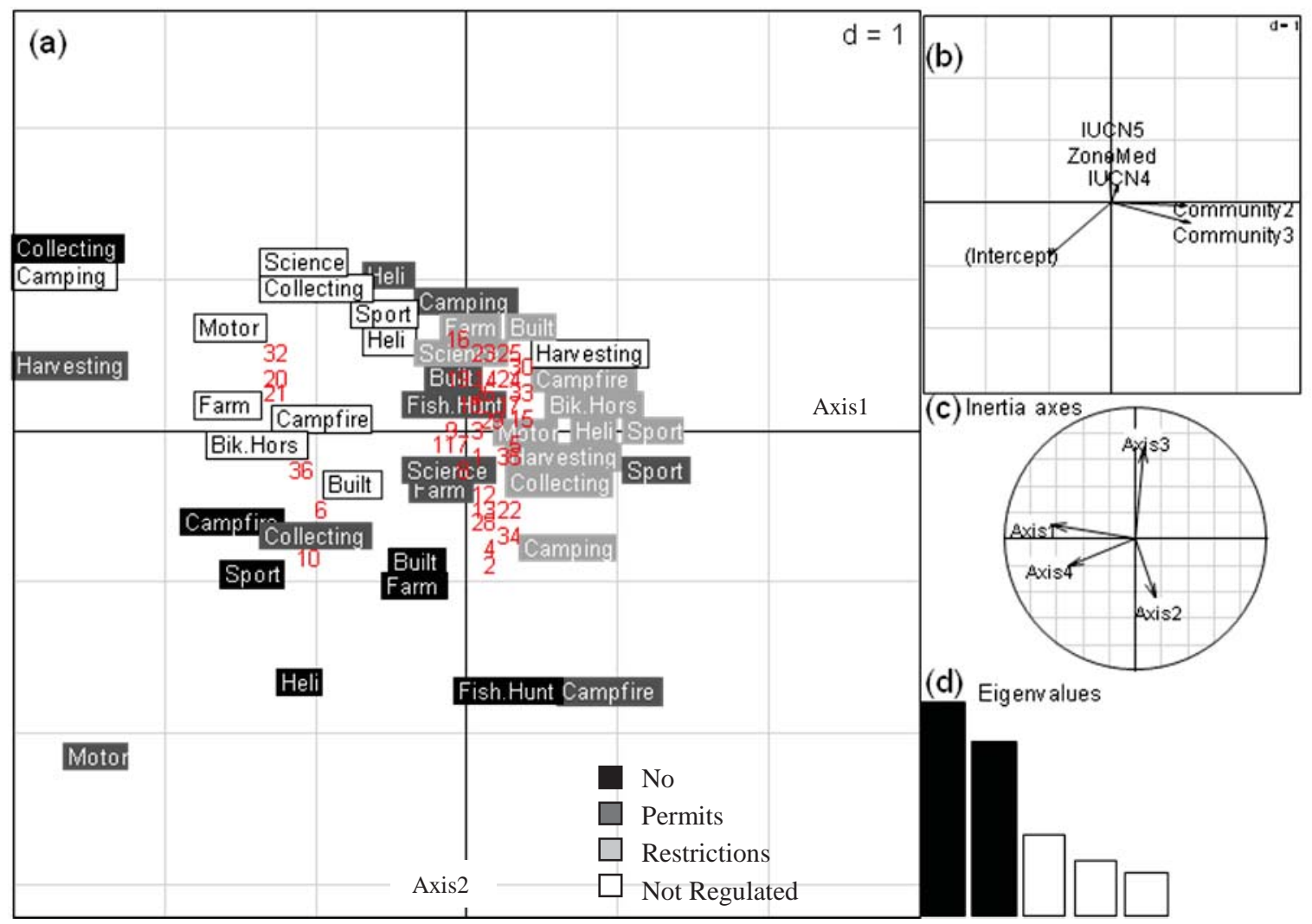

\subsection{Discussion}

In this paper we rhetorically asked "What do the IUCN categories really protect?". Given the strong emphasis on PA coverage as a key measure of biodiversity conservation globally, this question needs to be answered. Our systematic study of policies in alpine PAs in Spain shows that many of the parks have vague goals and do not clearly state how biodiversity should be prioritized among other goals in the parks. The suggestion by some authors to use only the strictest categories (I-IV) as biodiversity conservation measures (e.g. Locke and Dearden, 2005) is neither sufficient for the Spanish Alpine PAs as aims are not reflected by stricter management practices in the higher protection level categories. Therefore categories do not provide the efficient guidance for managers to prioritize biodiversity against other goals. The lack of management plans in 50\% of the PAs (Europarc-España, 2012) also strengthens the argument that biodiversity conservation in the Spanish PA's are weakly regulated. Albeit the lack of conservation measures to comprehensively answer our question, we share the concern of scholars who claim that the IUCN designations do not necessarily reflect how well the PAs perform in halting biodiversity loss.

Clear management objectives play a crucial role for adaptive management of ecosystems (Williams, 2011). Clear, measurable, and agreed-upon objectives allow for evaluation of performance, identification of uncertainties, and increase the effectiveness of PA management. As in many other 
countries (e.g. Borgerhoff Mulder and Coppolillo, 2005; Naughton-Treves et al., 2005), Spanish PAs have vague goals and tradeoffs between contradictory goals are not clearly stated (RodríguezRodríguez and Martínez-Vega, 2012). Usually biodiversity protection is mentioned together with other social, economic and political goals without clear guidance for on-site management in PAs (Chape 2004; Chape et al., 2005). Recently developed evaluation frameworks, such as SIAPA, allow for assessment of protected area effectiveness despite the lack of management objectives and plans (Rodríguez-Rodríguez and Martínez-Vega, 2012). For conservation purposes, however, on-site management needs guidance to prioritize biodiversity against all other competing goals, as well as regulatory policies which allow them to do so.

IUCN categories provide a standard framework that allows comparisons between PAs (Chape, 2004). A study conducted by Dillon (2004) shows that the Spanish 1989 Act mostly reflects the 1978 IUCN category system, but our study shows mismatches with the 1994 IUCN category system. A study conducted by Mierauskas (2004) in Lithuania analyzed categories Ia and Ib and showed that the PA system and management goals diverge substantially from the IUCN categories. He concluded that goals and regulations defined in the law did not correspond with the IUCN defined categories. Locke and Dearden (2005) argued that categories V and VI are often designated for human use rather than for biodiversity conservation. Therefore, the rapid increase in PA designation since 1992 does not reflect the real progress towards biodiversity conservation, because almost half of the new PAs (47.9\%) correspond to categories V and VI (Locke and Dearden, 2005). We also found that Spain is far from assigning international categories to Spanish PAs (compromise adopted by the 2007 Act). According to EUROPARC-España (2012) only the 30\% of the Spanish PAs have an IUCN category assigned, and the category $\mathrm{V}$ is the designation most commonly used.

Our study shows that, for regulations, the Autonomous Communities explain as much of the variance as the IUCN categories. In particular the Autonomous Communities that passed their laws at a later stage regulate human activities in the park to a larger extent. Such patterns have also been evident in other countries, as management is usually adapted to a larger system of PAs already in place (Hobbs et al., 2010), rather than to the IUCN categories. Devolution of authority has been a core issue in the latest years. The outcome of community-based management is mixed and often dependent on a range of other conditions than the governing body (Hayes, 2006; Bray, 2007; Ostrom, 2007; Schelhas and Pfeffer, 2009; Berkes, 2010). Our study does not allow an analysis of the conservation performance of the parks, but the lack of a general pattern in regulations (except for the weak effect of epochs of declaration by Autonomous Communities) indicate that management practices are individually governed by the Autonomous Communities rather than standardized according to international policies.

Management aims and regulations influence the later management actions and thus the outputs and outcomes. The use of content analyses of aims and regulations as a standardized evaluation method allows comparisons between different countries, and could be used as a first indication of the extent of prioritization of biodiversity goals in PAs. The lack of appropriate policies calls for the use of other approaches for PA effectiveness evaluation. Some studies have focused on the level of human disturbances in PAs, such as the naturalness level of the area (Liu et al., 2001; Ellis and Porter- 
Bolland, 2008; Nagendra, 2008; Leroux et al., 2010) or the ecological integrity of the system (Parrish et al., 2003; Karr, 2004). Such evaluations have been criticized for confusing terms such as "naturalness", "rarity" or "representativeness", and the use of broad concepts (e. g. diversity, can be genes, species or ecosystem diversity) (Smith and Theberge, 1986; Cole et al., 2008). Furthermore, data obtained from monitoring populations or biodiversity are hard to compare between sites (Stem, 2005). In practice the most common approach to evaluation has been qualitative, such as scorecards, expert judgment and experience-based knowledge (Ervin, 2003; Stem et al., 2005; Cook et al. 2010; Quan et al., 2011). These evaluation methods do not necessarily directly link conservation interventions and conservation impacts, except through the experts own evaluations (Stem, 2005). According to scholars of evidence-based conservation such experience-based knowledge is not sufficient, and more research is therefore needed to assess conservation outcomes, including the associated causes (Pullin and Knight, 2001; Sutherland et al. 2004; Cook et al. 2010). Analyses of policy gaps in conservation could in such cases guide the selection of PAs which need in-depth analyses of conservation outcomes.

A management plan is crucial for the use of PAs coverage as an indicator, as the performance of "paper parks" is hard to assess (Bruner et al., 2001). The criterion of selecting only the parks with management plans reduced the number of PAs available for our analysis. Although this could introduce some biases, the lack of management plans strengthens our argument that there is a general lack of guidance for the prioritization of biodiversity versus other goals. Such analyses of management plans are not too costly and could identify potential weaknesses in the PA systems as well as needs for further monitoring and evaluations.

\section{Conclusions}

Systematic evaluation of the management plans of the parks could be an efficient first step prior to other evaluation and monitoring programs, by identifying potential weaknesses, such as the lack of explicit prioritization of biodiversity against other needs in the Spanish alpine PAs. Aims and regulations should also be analyzed with regard to the authority in charge of management, since different governing systems may affect the restriction level applied to the PA. Our study shows that the designation by the Autonomous Communities according to different conservation laws was as important as the IUCN categories for explaining patterns in regulations. The overall weak correspondence in management practices among PAs also indicates that management is influenced by other factors than international standards.

The first step of policy analysis should be succeeded by a more complete evaluation of management effectiveness such as PAME (Hockings, 2006), or Protected Areas Effectiveness Evaluations such as SIAPA (Rodríguez-Rodríguez and Martínez-Vega, 2012), or simply by in-depth biological studies in PAs where our analyses detect mismatches in international and local policies. To truly answer our title question, the policy analyses need to be combined with the analyses of threats and conservation outcomes, either through expert assessments or evidence-based conservation. 


\section{Acknowledgments}

We would like to thank Ingunn Tombre and Jenny Stien, whose comments and recommendations were very helpful.

\section{Appendix A. Supplementary data}

Supplementary data associated with the methodology used in this paper can be found in the Appendix A.

\section{Conflict of Interest}

"The authors declare no conflict of interest".

\section{References and Notes}

Banco de Datos de la Naturaleza. Common Database Designated Areas-CDDA. 2011.

Berkes, F. Devolution of environment and resources governance: trends and future. Environmental Conservation 2010, 37(4): 489-500.

BOE no.299. Ley 42/2007, de 13 de diciembre, del Patrimonio Natural y de la Biodiversidad. 5127551327.

Borgehoff Mulder, M.; Coppolillo, P. Conservation: linking ecology, economics, and culture. Princeton University Press, Princeton, New Jersey, USA, 2005.

Bottrill, M.C.; Hockings, M.; Possingham, H.P. In Pursuit of Knowledge: Addressing Barriers to Effective Conservation Evaluation. Ecology and Society 2011, 16(2): 14.

Bray, D.B.; Durán, E.; Merino, L.; Torres, J.M.; Velázquez, A. Nueva evidencia: Los bosques comunitarios de México. Protegen el ambiente, disminuyen la pobreza y promueven la paz social. Consejo Civil Mexicano para la Silvicultura Sostenible. Mexico. 2007.

Bruner, A.G.; Gullison, R.E.; Rice, R.E.; Da Fonseca, G.A.B. Effectiveness of Parks in Protecting Tropical Biodiversity. Science 2001, 291:125-127.

Butchart, S. H. M. Et al. Global biodiversity: indicators of recent declines. Science 328, 1164-1168 (2010)

CBD. Decisions adopted at the Conference of the Parties to the Convention of Biological Diversity at its Eighth meeting. Convention of Biological Diversity, UNEP/CBD/COP/8. Curitiba, Brazil. 2006.

CBD. Decisions adopted at the Conference of the Parties to the Convention of Biological Diversity at its Tenth meeting. Convention on Biological Diversity, UNEP/CBD/COP/10. Nagoya, Japan. 2010.

Chape, S. Systematic assignment of protected area management categories: an opportunity for achieving a measurable framework. Parks 2004,14(3):51-57.

Chape, S.; Harrison, J.; Spalding, M.; Lysenko, I. Measuring the extent and effectiveness of protected areas as indicator for meeting global biodiversity targets. Philosophical Transactions of The Royal Society 2005, 360:443-455.

Coad, L.; Burgess, N.; Fish, L.; Ravillious, C.; Corrigan, C.; Pavese, H.; Granziera, A.; Besançon, C. Progress towards the Convention on Biological Diversity terrestrial 2010 and marine 2012 targets for protected area coverage. Parks 2004, 17(2):35-42.

Cole, D. N.; Yung, L., Zavaleta, E. S.; Aplet, G. H.; Chaplin, F. S. III; Graber, D. M.; Higgs, E. S.; Hobbs, R. J.; Landres, P. B.; Millar, C. I.; Parsons, D. J.; Randall, J. M.; Stephenson, N. L.; Tonnessen, K. A.; White, P. S.; Woodley, S. Naturalness and Beyond: Protected Area Stewardship in an Era of Global Environmental Change. The George Wright Forum 2008, 25(1):36-56.

Cook, C.N.; Hockings, M.; Carter, RW.B. Conservation in the dark? The information used to support management decisions. Frontier in Ecology and in the Environment 2010, 8(4):181-186. 
Dillon, B. The use of the categories in national and international legislation and policy. Parks 2004, 14(3): 15-22.

Dray, S.; Dufour, A.B. The ade4 package: implementing the duality diagram for ecologists. Journal of Statistical Software 2007, 22(4): 1-20.

Dudley, N. (Editor). Guidelines for Applying Protected Area Management Categories. Gland, Switzerland, IUCN. 2008. X + 86p.

Eagles, P. F. J.; McCool, S. F. Tourism in National Parks and Protected Areas: Planning and Management. England: CABI. 2002. Xii+320p.

Ellis, E.A.; Porter-Bolland, L. Is community-based forest management more effective than protected areas? A comparison of land use/land cover change in two neighboring study areas of the Central Yucatan Peninsula, Mexico. Forest Ecology and Management 2008, 256: 1971-1983.

Ervin, J. Protected Area Assessments in Perspective. BioScience 2003, 53(9): 819-822.

Erwin, T.L. An Evolutionary Basis for Conservation Strategies. Science 1991, 253:750-752.

ESRI (Environmental Systems Resource Institute). ArcMap 10.0. Redlands, California. 2010.

EUROPARC-España. Procedimiento para la asignación de las categorías internacionales de manejo de áreas protegidas de la UICN. Ed. Fundación Fernando González Bernáldez. Madrid. 2008. 140 p.

EUROPARC-España. Anuario EUROPARC-España del estado de los espacios naturales protegidos 2009. Ed. FUNGOBE. Madrid. 2010a. 104p.

EUROPARC-España. Herramientas para la evaluación de las áreas protegidas: modelo de memoria de gestión. Ed. Fundación Interuniversitaria Fernando González Bernáldez para los Espacios Naturales. Madrid. 2010b. 121 p.

EUROPARC-España. Observatorio de los Espacios Protegidos 2009. Manual del usuario. Ed. Fundación Interuniversitaria Fernando González Bernáldez para los Espacios Naturales. 2010c. 27p.

EUROPARC-España. Anuario 2011 del estado de las áreas protegidas en España. Ed. Fundación Fernando González Bernáldez. Madrid. 2012. 186 p.

European Commission. Natura 2000 network. 2012. Retrieved $7^{\text {th }}$ August 2012. From: http://ec.europa.eu/environment/nature/natura2000/index_en.htm

Ferraro, P.J.; Pattanayak, S.K. Money for Nothing? A Call for Empirical Evaluation of Biodiversity Conservation Investments. PloS Biology 2006, 4(4): 482-488.

Gaston, K. J.; Charman, K.; Jackson, S. F.; Armsworth, P. R.; Bonn, A.; Briers, R.; Callaghan, C.S.Q.; Catchpole, R.; Hopkins, J.; Kunin, W.E.; Latham, J.; Opdam, P.; Stoneman, R.; Stroud, D.A.; Tratt, R. The ecological effectiveness of protected areas: The United Kingdom. Biological Conservation 2006, 132 (1): 76-87.

Greenacre, M.J. Correspondence Analysis in Practice. Academic Press, London. 2n ed. 2007.

Greenacre, M.J. From Simple to Multiple Correspondence Analysis. In Greenacre, M.J.; Blasius, J; Gelman, A.; Rabe-Hesketh, S. (Eds.). Multiple Correspondence Analysis and Related Methods. Chapman \& Hall/CRC, Boca Raton. 2006. 41-76p.

Hausner, V.H.; Yoccoz, N.G.; Ims, R.A. Selecting Indicator Traits for Monitoring Land Use Impacts: Birds in Northern Coastal Birch Forests. Ecological Applications 2003, 13 (4):999-1012.

Hayes, T.M. Parks, People, and Forest Protection: An Institutional Assessment of the Effectiveness of Protected Areas. World Development 2006, 34(12): 2064-2075.

Hobbs, R.J.; Cole, D.N.; Yung, L.; Zavaleta, E.S.; Aplet, G.H.; Chapin, F.S.; Landres, P.B.; Parsons, D.J.; Stephenson, N.L.; White, P.S.; Graber, D.M.; Higgs, E.S.; Millar, C.I.; Randall, J.M.; Tonnessen, K.A.; Woodley, S. Guiding concepts for park and wilderness stewardship in an era of global environmental change. Frontiers in Ecology and the Environment 2010, 8(9): 483-490

Hockings, M. Systems for Assessing the Effectiveness of Management in Protected Areas. BioScience 2003, 53(9):823-832.

Hockings M.; Stolton, S.; Leverington, F.; Dudley, N.; Courrau, J. Evaluating Effectiveness: A framework for assessing management effectiveness of protected areas. $2^{\text {nd }}$ edition. IUCN, Gland, Switzerland and Cambridge, UK. 2006. Xiv+105 pp. 
Hsieh, H.; Shannon, S. Three approaches to qualitative content analysis. Qualitative Health Research 2005, 15:1277-1288.

Instituto Geográfico Nacional de España. Mapas generales de España. Retrieved 2012.

IUCN. Guidelines for Protected Area Management Categories. CNPPA with the assistance of WCMC. IUCN, Gland, Switzerland and Cambridge, UK. 1994. X+261p.

Joppa, L.N.; Loarie, S.R.; Pimm, S.L. On the protection of "protected areas". PNAS 2008, 105(18):6673-6678.

Karr, J.R. Beyond Definitions: Maintaining Biological Integrity, Diversity, and Environmental Health in National Wildlife Refuges. Natural Resources Journal 2004, 44:1067-1092.

Killengreen, S.T.; Strømseng, E.; Yoccoz, N.G.; Ims, R.A. How ecological neighbourhoods influence the structure of the scavenger guild in low arctic tundra. Diversity and Distributions 2012, 18:563574.

Lebreton, J.D.; Sabatier, R.; Banco, G.; Bacou, A.M. Principal component and correspondence analyses with respect to instrumental variables: an overview of their role in studies of structureactivity and species-environment relationships. In Devillers, J. and W. Karcher (eds). Applied Multivariate Analysis in SAR and Environmental Studies 1991, 85-114.

Leroux, S.J.; Krawchuk, M.A.; Schmiegelow, F.; Cumming, S.G.; Lisgo, K.; Anderson, L.G.; Petkova, M. Global protected areas and IUCN designations: Do the categories match the conditions?. Biological Conservation 2010, 143:609-616.

Leverington, F.; Costa, K.L.; Pavese, H.; Lisle, A.; Hockings, M. A Global Analysis of Protected Area Management Effectiveness. Environmental Management 2010, 46:685-698.

Liu, J.; Linderman, M.; Ouyang, Z.; An, L.; Yang, J.; Zhang, H. Ecological Degradation in Protected Areas: The Case of Wolong Nature Reserve for Giant Pandas. Science 2001, 292: 98-101.

Locke, H.; Dearden, P. Rethinking protected area categories and the new paradigm. Environmental Conservation 2005, 32(1): 1-10.

Mierauskas, P. An Evaluation of the Strict Nature Reserves Management in Lithuania and their Correspondence to International Requirements. Environmental research, engineering and management 2004, 3(29): 62-70.

Mulero Mendigorri, A. La protección de Espacios Naturales en España. Antecedentes, contrastes territoriales, conflictos y perspectivas. Mundiprensa. Madrid. 2002. 309p.

Mulero Mendigorri, A. Notas en torno a la Ley del Patrimonio Natural y de la Biodiversidad (Ley 42/2007, de 13 de diciembre): Alcance y aportaciones básicas. Revista de Estudios regionales 2008, 88: 265-313.

Mücher, C.A.; Wascher, D.M.; Klijn, J.A.; Koomen, A.J.M.; Jongman, R.H.G. A new European Landscape Map as an integrative framework for landscape character assessment. In R.G.H. Bunceand R.H.G. Jongman (Eds). Landscape Ecology in the Mediterranean: inside and outside approaches. Proceedings of the European IALE Conference 29 March - 2 April 2005 Faro, Portugal. IALE Publication Series 2006, 3:233-243.

Nagendra, H. Do Parks Work? Impact of Protected Areas on Land Cover Clearing. AMBIO: A Journal of the Human Envrionment 2008, 37(5): 330-337.

Naughton-Treves, L; Holland, M.B.; Brandon, K. The role of protected areas in conserving biodiversity and sustaining local livelihoods. Annual Review of Environment and Resources 2005, 30: 219-252.

Ostrom, E. A diagnostic approach for going beyond panaceas. PNAS 2007, 104(39): 15181-15187.

Parrish, J.D.; Braun, D.P.; Unnasch, S. Are We Conserving What We Say We Are? Measuring Ecological Integrity within Protected Areas. BioScience 2003, 53(9):851-860.

Pullin, A.S.; Knight, T.M. Effectiveness in Conservation Practice: Pointers from Medicine and Public Health. Conservation Biology 2001, 15(1): 50-54.

Quan, J.; Ouyang, Z.; Xu, W.; Miao, H. Assessment of the effectiveness of nature reserve management in China. Biodiversity Conservation 2011, 20: 779-792. 
R Development Core Team. R: A language and environment for statistical computing. $R$ Foundation for Statistical Computing. Vienna, Austria. 2011. ISBN 3-900051-07-0, URL http://www.Rproject.org/.

Rand, M.; Spalding, M.; Sanjayan, M. Paper Parks Re-Examines: Building a Future for "MPAs-inWaiting”. MPA news 2012, 13(4):1-3.

Rao, C.R. The Use and Interpretation of Principal Component Analysis in Applied Research. The Indian Journal of Statistics, Series A 1964, 26 (4):329-358.

Schelhas, J.; Pfeffer, M.J. When global environmentalism meets local livelihoods: policy and management lessons. Conservation letters 2009, 2(6): 278-285.

Rodríguez-Rodríguez, D.; Martínez-Vega, J. Proposal of a system for the integrated and comparative assessment of protected areas. Ecological indicators 2012, 23:566-572.

Smith, P.G.R.; Theberge, J.B. A review of Criteria for Evaluating Natural Areas. Environmental Management 1986, 10(6):715-734.

Stem, C.; Margoluis, R.; Salafsky, N.; Brown, M. Monitoring and Evaluation in Conservation: a Review of Trends and Approaches. Conservation Biology 2005, 19(2): 295-309.

Stoll-Kleemann S.; Job, H. The Relevance of Effective Protected Areas for Biodiversity Conservation: An Introduction. GAIA 2008, 17 (S1):86-89.

Stolton, S. Issues that arise for the categories in a changing world. Parks 2004, 14(3):63-71.

Sutherland, W.J.; Pullin, A.S.; Dolman, P.M.; Knight, T.M. The need for evidence-based conservation. Trends in Ecology and Evolution 2004, 19(6): 305-308.

Tenenhaus, M.; Young, F.W. An analysis and synthesis of multiple correspondence analysis, optimal scaling, dual scaling, homogeneity analysis and other methods for quantifying categorical multivariate data. Psychometrika 1985, 50(1): 91-119

Ter Braak, C. J. F. Canonical Correspondence Analysis: A New Eigenvector Technique for Multivariate Direct Gradient Analysis. Ecology 1986, 67(5): 1167-1179.

Thioulouse, J. Simultaneous analysis of a sequence of paired ecological tables: A comparison of several methods. The Annals of Applied Statistics 2011, 5(4):2300-2325.

Tolón Becerra, A.; Lastra Bravo, X. Los Espacios Naturales Protegidos. Concepto, evolución y situación actual en España. M+A Revista Electrónica de Medioambiente, UCM 2008, 1-25.

Troitiño Vinuesa, M.A. Espacios Naturales Protegidos y Desarrollo Rural: Una Relación Territorial Conflictiva. Boletín de la A.G.E. 1995, 20:23-37.

Vacas Guerrero, T. Los espacios naturales protegidos: figuras de protección en España. Actas del XIX Congreso de Geógrafos Españoles: Espacios públicos, espacios privados. Asociación de Geógrafos Españoles, Universidad de Cantabria. 2005.

Williams, B.K. Adaptive management of natural resources-framework and issues. Journal of Environmental Management 2011, 92: 1346-1353.

(C) 2011 by the authors; licensee MDPI, Basel, Switzerland. This article is an open access article distributed under the terms and conditions of the Creative Commons Attribution license (http://creativecommons.org/licenses/by/3.0/). 
Appendix A

A 1: List of the management aims studied. Source: IUCN guidelines 1994.

\begin{tabular}{llllllll}
\hline Management objective & Ia & Ib & II & III & IV & V & VI \\
\hline Scientific research & 1 & 3 & 2 & 2 & 2 & 2 & 3 \\
\hline Wilderness protection & 2 & 1 & 2 & 3 & 3 & - & 2 \\
Preservation of species and genetic diversity & 1 & 2 & 1 & 1 & 1 & 2 & 1 \\
Maintenance of environment services & 2 & 1 & 1 & - & 1 & 2 & 1 \\
Protection of specific natural / cultural features & - & - & 2 & 1 & 3 & 1 & 3 \\
\hline Tourism and recreation & - & 2 & 1 & 1 & 3 & 1 & 3 \\
Education & - & - & 2 & 2 & 2 & 2 & 3 \\
Sustainable use of resources from natural ecosystems & - & 3 & 3 & - & 2 & 2 & 1 \\
Maintenance of cultural / traditional attributes & - & - & - & - & - & 1 & 2 \\
1 Primary objective & & & & & & & \\
2 Secondary objective & & & & & & & \\
$\mathbf{3} \quad$ Potentially applicable objective & & & & & & & \\
$-\quad$ Not applicable & & & & & & \\
\hline
\end{tabular}

A 2: List of the regulations and the question we asked for each one.

\begin{tabular}{ll}
\hline Activity code & Definition \\
\hline Camping & Is camping allowed everywhere? \\
\hline Campfire & Are campfires allowed? \\
\hline Motor & Are motorized vehicles allowed within the boundaries? \\
Heli & Is the use of air-vehicles allowed? \\
Sport & Can sports competitions be played? \\
\hline Bik+Hors & Are bikes and horse riding allowed within the boundaries? \\
\hline Fish+Hunt & Is fishing and hunting allowed? \\
Collecting & Can mushrooms, fruits and plants be collected? \\
Harvesting & Is extensive harvesting allowed (grazing, firewood extranction)? \\
Farm & Are new intensive farms allowed? \\
\hline Built & Is building allowed (private houses and touristic infrastructure)? \\
Science & Are scientific activities allowed? \\
\hline
\end{tabular}

